\title{
Pinanamine Is a Promising Lead Compound against Influenza A Virus: Evidence from in Vitro and in Vivo Efficacy Compared to Amantadine
}

\author{
Runfeng Li,${ }^{a, \#}$ Chunguang Yang,,${ }^{a, \#}$ Qiuling Du, ${ }^{a}$ Xin Zhao, ${ }^{b}$ Haiming Jiang, ${ }^{a}$ Wenhui Hu, ${ }^{* a, b}$ and \\ Zifeng Yang*,a,c \\ ${ }^{a}$ State Key Laboratory of Respiratory Disease, National Clinical Research Center for Respiratory Disease, \\ Guangzhou Institute of Respiratory Disease, First Affiliated Hospital of Guangzhou Medical University (Guangzhou \\ Medical University); Guangzhou 510120, China: ${ }^{b}$ National Clinical Research Center for Respiratory Disease; \\ Guangzhou 510120, China: and ${ }^{c}$ Macau University of Science and Technology; Avenida Wai Long, Taipa, Macau \\ 519020, China.
}

Received September 29, 2016; accepted March 21, 2017

Influenza A viruses with the presence of mutations in M2 still circulate and threaten to avian species and human in China. A novel M2 inhibitor pinanamine was previously identified as an antiviral agent by an in vitro assay. In this study, we monitored the activity of pinanamine against influenza A/FM1/47 (H1N1) virus infection in cell culture and mice. Pinanamine showed more potent antiviral effect than ribavirin, and was as effective as oseltamivir carboxylate and amantadine in Madin-Darby canine kidney (MDCK) cells. Pinanamine at dose of $50 \mathrm{mg} / \mathrm{kg} / \mathrm{d}$ administrated once a day for $6 \mathrm{~d}$ starting $24 \mathrm{~h}$ prior to virus exposure promoted survival rate of infected mice to $100 \%(p<0.001)$ and produced significant reduction $(p<0.001)$ in lung virus yields and lung index. Even lower the dose of $3.1 \mathrm{mg} / \mathrm{kg} / \mathrm{d}$, pinanamine was $60 \%$ protective $(p<0.05)$, which was equivalent to treatment with amantadine at $50 \mathrm{mg} / \mathrm{kg} / \mathrm{d}$. Our finding highlights the potential of pinanamine as a promising lead compound for influenza A virus.

Key words pinanamine; M2 inhibitor; influenza A virus; in vivo; in vitro

Influenza A viruses are classified by subtype on the basis of two surface proteins hemagglutinin (HA) and neuraminidase (NA). Until now there are $18 \mathrm{HA}$ and 11 NA subtypes detected in influenza A virus throughout the world. ${ }^{1)}$ Influenza A virus poses constant threats to human health around the world each year. Human influenza A virus often results in acute respiratory infections of varying severity, ranging from asymptomatic infections to a fatal disease. ${ }^{2)}$ The most severe human influenza pandemic occurred from 1918 to 1919, with 20 million deaths worldwide. ${ }^{3)}$ Seasonal influenza A virus and pandemic H1N1 influenza $\mathrm{A}$ virus have also been periodically associated with high mortality rates. In addition, the continued lethal disease in humans associated with highly pathogenic avian influenza (HPAI) H5N1 virus infection has drawn attention to its pandemic risk, ${ }^{4}$ and viruses have evolved into different clades with varying degrees of sensitivity to amantadine. ${ }^{5)}$ Recent outbreak of zoonotic H7N9 avian influenza virus in China has reminded us another unexpected virus posing to human health. ${ }^{6)}$ Since February 2013, WHO has reported 1115 confirmed human cases of H7N9 virus with 379 deaths in China, including three human cases originated in China and were reported in Malaysia (1) and Canada (2). ${ }^{7}$

The considerable morbidity and mortality in human populations due to influenza A virus suggest that this virus remains a major emerging pathogen of global concern.

Currently two classes of antiviral drugs were licensed for the treatment and prophylaxis of influenza viruses, primarily M2 ion channel inhibitors (amantadine and rimantadine) and neuraminidase inhibitors (zanamivir, oseltamivir, laninamivir and peramivir) ${ }^{8}{ }^{8}$ Though resistance to both antiviral classes has been increasingly documented globally, ${ }^{9,10)}$ some studies

\footnotetext{
${ }^{\#}$ These authors contributed equally to this work.

have indicated that amantadine-sensitive reassortant $\mathrm{H} 1 \mathrm{~N} 1$ virus became predominant in Japan during the 2007-2008 season. ${ }^{11)}$ Therefore, the M2 inhibitor appears to be potential in treating patients infected with these amantadine-sensitive viruses. However, the limitation remains that the central nervous system (CNS) is one of the primary target sites of amantadine toxicity. ${ }^{12)}$ Developing amantadine derivatives which are effective against the resistant mutants and amantadinesensitive viruses may be one of the promising ways to fight against influenza A virus infection.

Our previous study identified a novel M2 blocker, namely $(1 R, 2 R, 3 R, 5 S)$-3-pinanamine, through a focused screening of a small primary amine library using a scaffold-hopping strategy based on amantadine. The pinanamine showed similar activity to amantadine in inhibiting amantadine-sensitive influenza $\mathrm{A} /$ Hong Kong/8/68 (H3N2) virus in vitro, ${ }^{13)}$ we further designed and synthesized several pinanamine derivatives by linking the alkali group to the scaffold in an attempt to generate compounds against amantadine-resistant virus. ${ }^{14,15)}$ Interestingly, several compounds of this pinanamine derivatives could inhibit the amantadine-sensitive virus at low micromolar concentrations. $^{16)}$ Therefore, exploring novel pinanamine-based M2 inhibitors that target the amantadine-resistant influenza A virus is of great interest. However, pinanamine as a lead compound, the in vivo efficacy of pinanamine remains unknown. In the study described here, we evaluated the inhibition of influenza A/FM1/47 (H1N1) virus by pinanamine in vitro, and we compared the efficacy of pinanamine and amantadine in mice infected with a lethal dose of H1N1 virus. The results indicate that pinanamine could qualify as a promising lead compound for the discovery of drugs active against the influenza A virus. 
A

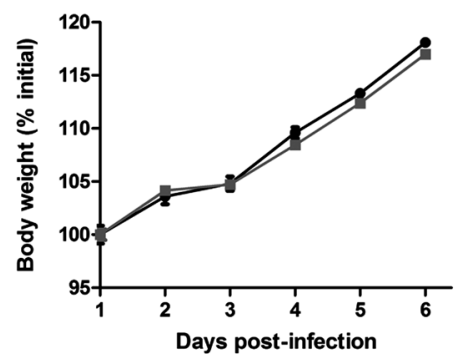

C

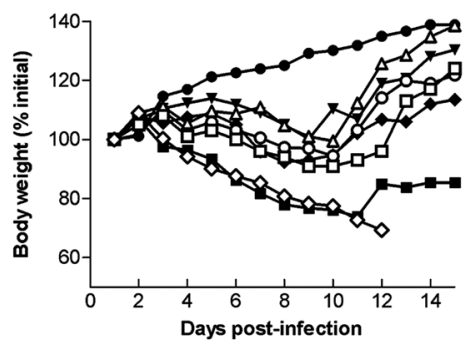

- normal control pinanamine $(50 \mathrm{mg} / \mathrm{kg} / \mathrm{d})$
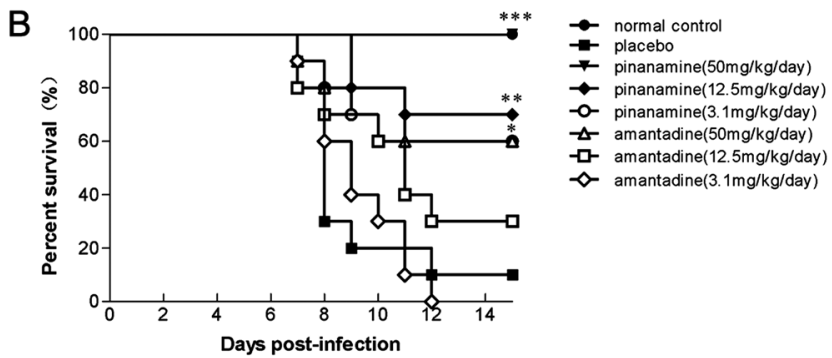

Fig. 1. Efficacy of Pinanamine on Survival of Mice Challenged with H1N1 Influenza Virus

Infected mice were orally administered pinanamine or sterile water (placebo-treated control) at the indicated doses once daily for $6 \mathrm{~d}$, beginning $24 \mathrm{~h}$ before infection. (A) Body weight change in mice receiving pinanamine dose of $50 \mathrm{mg} / \mathrm{kg} / \mathrm{d}$ for $6 \mathrm{~d}$. (B) Survival outcome of H1N1 virus-infected mice for $15 \mathrm{~d}$. Compared with the results for the placebo-treated control $(* p<0.05 ; * p<0.01 ; * * *<<0.001)$. (C) Body weight change in infected mice for $15 \mathrm{~d}$. (D) The difference about MDD in mice receiving pinanamine and amantadine compared with the placebo-treated group.

\section{MATERIALS AND METHODS}

Compounds Pinanamine was obtained as previously reported. ${ }^{13)}$ Amantadine (1-adamantanamine hydrochloride; CAS Registry Number 665-66-7) and ribavirin were purchased from Sigma (U.S.A.). Oseltamivir carboxylate was provided by F. Hoffmann-La Roche Ltd. (Switzerland) (Fig. 1). All samples were prepared in Dulbecco's modified Eagle's medium (DMEM) for in vitro evaluation, and in sterile water for in vivo study.

Cells and Viruses Madin-Darby canine kidney (MDCK) cells were obtained from the American Type Culture Collection (ATCC) and maintained in DMEM supplemented with $10 \%$ fetal bovine serum (FBS) and $1 \%$ penicillin-streptomycin. Amantadine-susceptible influenza A/FM1/47 (H1N1) virus was obtained from ATCC, and it acquired lethal virulence through 7 passages in mouse lungs. Virus pools were used to titrate by $50 \%$ tissue culture infectious dose $\left(\mathrm{TCID}_{50}\right)$ in MDCK cells, and infect mice to determine the $50 \%$ mouse lethal dose $\left(\mathrm{MLD}_{50}\right)$ after a 15 -d observation period prior to use. The $\mathrm{TCID}_{50}$ and $\mathrm{MLD}_{50}$ values were $10^{7} / \mathrm{mL}$ and $10^{5.8} / \mathrm{mL}$ respectively, calculated by the Reed-Muench method. ${ }^{17)}$

Animals Specific-pathogen-free (SPF) female BALB/c mice (16 to $22 \mathrm{~g}$ ) were obtained from Guangdong Laboratory Animal Center. The mice were quarantined for $48 \mathrm{~h}$ prior to infection, fed on standard mouse chow and given water ad libitum.

In Vitro Antiviral Assay Antiviral efficacy was determined in parallel by a viral cytopathic effect (CPE) assay and plaque reduction assay. In CPE assay, MDCK cells were grown to a confluent monolayer in a 96 -well culture plate for $24 \mathrm{~h}$. The medium was removed, and the cells were rinsed twice. An infectious virus at $100 \mathrm{TCID}_{50}$ was inoculated into the MDCK cells, which were then incubated for $2 \mathrm{~h}$ at $37^{\circ} \mathrm{C}$ in
$5 \% \mathrm{CO}_{2}$. The virus supernatant was then removed, followed by the addition of serial two-fold dilutions of antiviral compounds in DMEM containing $1.5 \mu \mathrm{g} / \mathrm{mL}$ trypsin. After being incubated at $37^{\circ} \mathrm{C}$ in $5 \% \mathrm{CO}_{2}$ for $48 \mathrm{~h}$, the infected cells displayed 100\% CPE under the microscope, and the CPE percentages in the antiviral compound-treated groups were recorded.

For plaque reduction assay, monolayer MDCK cells in a 24-well culture plate were rinsed twice, and incubated with 40 plaque-forming unit (PFU) of influenza virus. After incubated at $37^{\circ} \mathrm{C}$ for $2 \mathrm{~h}$, the media was discarded, and the cells of each well were overlaid by $0.8 \mathrm{~mL}$ of the agar/basic media mixture, which contained $0.8 \%$ agar (Agar No. 1, Oxoid), 0.01\% diethylaminoethyl (DEAE) dextran (MP Biomedicals, Inc., U.S.A.), $1.5 \mu \mathrm{g} / \mathrm{mL}$ trypsin (Sigma-Aldrich, U.S.A.) and various concentrations of compounds. The plate was maintained in $37^{\circ} \mathrm{C}$ for $3 \mathrm{~d}$, followed by removing the solid overlay in each well. The monolayer was fixed with $4 \%$ formalin and stained with $0.1 \%$ crystal violet to visualize and count the plaques. The $50 \%$ virus inhibitory concentration $\left(\mathrm{IC}_{50}\right)$ and $90 \%$ virus inhibitory concentration $\left(\mathrm{IC}_{90}\right)$ values were calculated.

Cytotoxicity assessment was conducted by 3-(4,5-dimethylthiazol-2-yl)-2,5-diphenyltetrazolium bromide (MTT) assay. Briefly, MDCK cells in 96-well plate were incubated for $48 \mathrm{~h}$ in DMEM, which contained different concentrations of test compounds in a series of 2-fold dilution. Then added $20 \mu \mathrm{L}$ of MTT stock solution $(5 \mathrm{mg} / \mathrm{mL})$ to each well and incubated at $37^{\circ} \mathrm{C}$ for $4 \mathrm{~h}$. Formazen crystals were solubilized by addition of $150 \mu \mathrm{L}$ dimethyl sulfoxide (DMSO) solution. Absorbance was read at $490 \mathrm{~nm}$ using Thermo multiskan MK3 spectrum spectrophotometer. The $50 \%$ cytotoxicity concentration $\left(\mathrm{CC}_{50}\right)$ values were calculated.

Animal Experimental Design The mice (14/group) were lightly anesthetized through the inhalation of diethyl ether, and they were intranasally inoculated with $5 \mathrm{MLD}_{50}(50 \mu \mathrm{L})$ of 
H1N1 virus. Pinanamine (50, 12.5 and $3.1 \mathrm{mg} / \mathrm{kg} / \mathrm{d})$ or amantadine $(50,12.5$ and $3.1 \mathrm{mg} / \mathrm{kg} / \mathrm{d})$ was orally administered to the mice, and the administration of each compound was initiated $24 \mathrm{~h}$ pre-infection. These drugs were then given once daily for $6 \mathrm{~d}$. Placebo and normal control animals received sterile water on the same schedule. In a survival rate study, the deaths and body weights were monitored daily for $15 \mathrm{~d}$. Four mice were killed on day 5 post-infection for virus titration of lung tissue. Briefly, each lung was homogenized to make a $10 \%$ (w/v) suspension. After cellular debris were removed by centrifugation at $10000 \times \boldsymbol{g}$ for $10 \mathrm{~min}$, supernatants were subjected to $\mathrm{TCID}_{50}$ determination using MDCK cells, and the TCID $_{50}$ values were calculated using the Reed-Muench method. ${ }^{17)}$ For the lung index study, same doses of virus and treatment were given to mice (8/group) as described above, and mice were killed on day 7 post-infection. The whole lung was removed, and rinsed in PBS, then dried with bibulous paper. The lung index was calculated as lung weight/body weight $\times 100 \%$ as described. ${ }^{18)}$ We employed various doses (ranged from $50-500 \mathrm{mg} / \mathrm{kg} / \mathrm{d}$ ) to access adverse effects of pinanamine according to weight loss and appearance of treated mice.

Immunochemistry The lungs from mice were collected on day 5 post-infection and fixed with $4 \%$ formalin, and then embedded in paraffin wax. Four-micrometer-thick sections were mounted on poly-L-lysine-coated slides. Antigen retrieval was performed in $10 \mathrm{~mm}$ sodium citrate, $\mathrm{pH} 6.0$ in a microwave. The endogenous peroxidase activity was inhibited using 3\% (v/v) $\mathrm{H}_{2} \mathrm{O}_{2}$. The slides were incubated with an antiinfluenza NP monoclonal antibody (mAb) (abcam, \#ab20343) at a 1:700 dilution in $4^{\circ} \mathrm{C}$ overnight, after incubating with polyclonal goat anti-mouse immunoglobulin $\mathrm{G}$ ( $\mathrm{IgG}$ ) antibodies (Jackson Immunoresearch Laboratories Inc., U.S.A. \#115-035-003) at a 1:250 dilution in room temperature for $1.5 \mathrm{~h}$. The $3,3^{\prime}$-diaminobenzidine (DAB) substrate was finally added to slides for $2 \mathrm{~min}$, influenza virus nucleoprotein were visualized as brown staining in optical microscope.

Statistical Analysis $\mathrm{The}_{\mathrm{IC}_{50}}$ and $\mathrm{IC}_{90}$ values were calculated using a non-linear regression model in GraphPad Prism. Statistical analysis of the survival rates was performed with the Wilcoxon test, and the Kaplan-Meier method was used for survival analysis. The lung index, viral load and mean days until death were calculated by $t$-test, Comparisons were made between placebo-treated and compounds-treated groups.

\section{RESULTS}

In Vitro Efficacy of Pinanamine against Influenza A Virus The cytotoxicity of pinanamine in MDCK cells was assessed by the MTT assay for $\mathrm{CC}_{50}$, comparing with those of oseltamivir, ribavirin and amantadine. Oseltamivir and ribavirin showed no cytotoxicity to cells at concentration up to $10000 \mu \mathrm{M}$. Toxicity was detected in pinanamine and amantadine, with $\mathrm{CC}_{50}$ values 1455 and $4949 \mu \mathrm{M}$, respectively (Table 1). The pinanamine potently inhibited virus with an $\mathrm{IC}_{50}$ value of $0.46 \mu \mathrm{M}$ by $\mathrm{CPE}$ assay and $0.33 \mu \mathrm{M}$ by plaque reduction assay. This inhibitory activity was similar to oseltamivir and amantadine, and better than ribavirin (Table 1). A lower selective index (SI) value was observed in pinanamine compared to oseltamivir and amantadine (Table 1).

Protection against Influenza A Virus Infection by Pinanamine in Vivo Five hundreds and $250 \mathrm{mg} / \mathrm{kg} / \mathrm{d}$ doses of pinanamine caused 50 and $25 \%$ death in uninfected mice, respectively, shortly after the first administration (data not shown). The survived mice in these groups presented ruffled fur and experienced slightly tremble during exposure time. Pinanamine doses of 100 and $50 \mathrm{mg} / \mathrm{kg} / \mathrm{d}$ was considered to be well tolerated, as all animal survived. The body weight change of mice receiving pinanamine dose of $50 \mathrm{mg} / \mathrm{kg} / \mathrm{d}$ for $6 \mathrm{~d}$ did not differ from that of normal control mice (Fig. 1A). Therefore, we employed $50 \mathrm{mg} / \mathrm{kg} / \mathrm{d}$ as the highest dosage for the drug efficacy study in vivo.

An experiment was conducted to evaluate the efficacy of pinanamine administrated at $24 \mathrm{~h}$ pre-infection in the survival outcome of lethal influenza (A/FM1/47, H1N1) virus infection (Fig. 1). As expected, most of the placebo-treated controls died (the survival rate was 10\%) (Fig. 1B), with mean day of death (MDD) of $8.44 \pm 1.42$ (Fig. 1D). However, the 12.5 and $3.1 \mathrm{mg} / \mathrm{kg} / \mathrm{d}$ pinanamine treatments conferred a survival benefit $(p<0.01$ and $p<0.05$, respectively) (Fig. 1B), even though no prolonged MDD was found in comparison to the placebo-treated controls ( $p>0.05$ ) (Fig. 1D). Encouragingly, a $50 \mathrm{mg} / \mathrm{kg} / \mathrm{d}$ dosage provided complete protection against death (the survival rate was 100\%) (Fig. 1B). An amantadine dosage of $50 \mathrm{mg} / \mathrm{kg} / \mathrm{d}$ increased the survival rate to $60 \%(p<0.05)$, and no markedly delayed death was observed $(p>0.05)$ (Figs. $1 B$, D). Orally administered pinanamine and amantadine reduced the extent of weight loss in infected mice compared with the placebo group (Fig. 1C), and transient weight loss was observed in all pinanamine-treated groups (Fig. 1C). Furthermore, Lower doses of amantadine $(12.5$ and $3.1 \mathrm{mg} / \mathrm{kg} / \mathrm{d})$ did not provide statistical significance in terms of survival and MDD compared with the placebo-treated group (Fig. 1D). These results indicate that pinanamine shows therapeutic potential for severe influenza A virus infection in mice under conditions in which amantadine exhibits lessened efficacy at the same dose.

To further understand the effects of pinanamine, the virus nucleoprotein expression and viral loads in lungs of infected

Table 1. In Vitro Efficacy of Pinanamine, Oseltamivir, Ribavirin and Amantadine ( $\mu \mathrm{M})$ against Influenza A (H1N1) Virus

\begin{tabular}{|c|c|c|c|c|c|c|c|}
\hline \multirow{2}{*}{ Compound } & \multirow{2}{*}{$\mathrm{CC}_{50}{ }^{a)}$} & \multicolumn{3}{|c|}{ CPE assay } & \multicolumn{3}{|c|}{ Plaque reduction assay } \\
\hline & & $\mathrm{IC}_{50}{ }^{b)}$ & $\mathrm{IC}_{90}{ }^{c)}$ & $\mathrm{SI}^{d)}$ & $\mathrm{IC}_{50}{ }^{b)}$ & $\mathrm{IC}_{90}{ }^{c)}$ & $\mathrm{SI}^{d)}$ \\
\hline Pinanamine & $1455 \pm 0$ & $0.46 \pm 0.04$ & $1.4 \pm 0.06$ & 3164 & $0.33 \pm 0.14$ & $1.1 \pm 0.2$ & 4409 \\
\hline Oseltamivir & $>10000$ & $0.54 \pm 0.1$ & $1.1 \pm 0.2$ & $>180000$ & $0.29 \pm 0.23$ & $0.8 \pm 0.19$ & $>300000$ \\
\hline Ribavirin & 15000 & $6.7 \pm 0.17$ & $12 \pm 0.28$ & 2000 & $9.6 \pm 0.21$ & $23 \pm 0.26$ & 1500 \\
\hline Amantadine & $4949 \pm 0.03$ & $0.58 \pm 0.03$ & $1.6 \pm 0$ & 8533 & $0.53 \pm 0.1$ & $1.6 \pm 0.1$ & 9337 \\
\hline
\end{tabular}

Data are presented as the mean \pm S.D. of the results of two independent tests, $\mathrm{CC}_{50}, \mathrm{IC}_{50}$ and $\mathrm{IC}_{90}$ values were calculated using a non-linear regression model in GraphPad

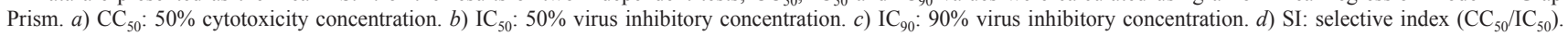




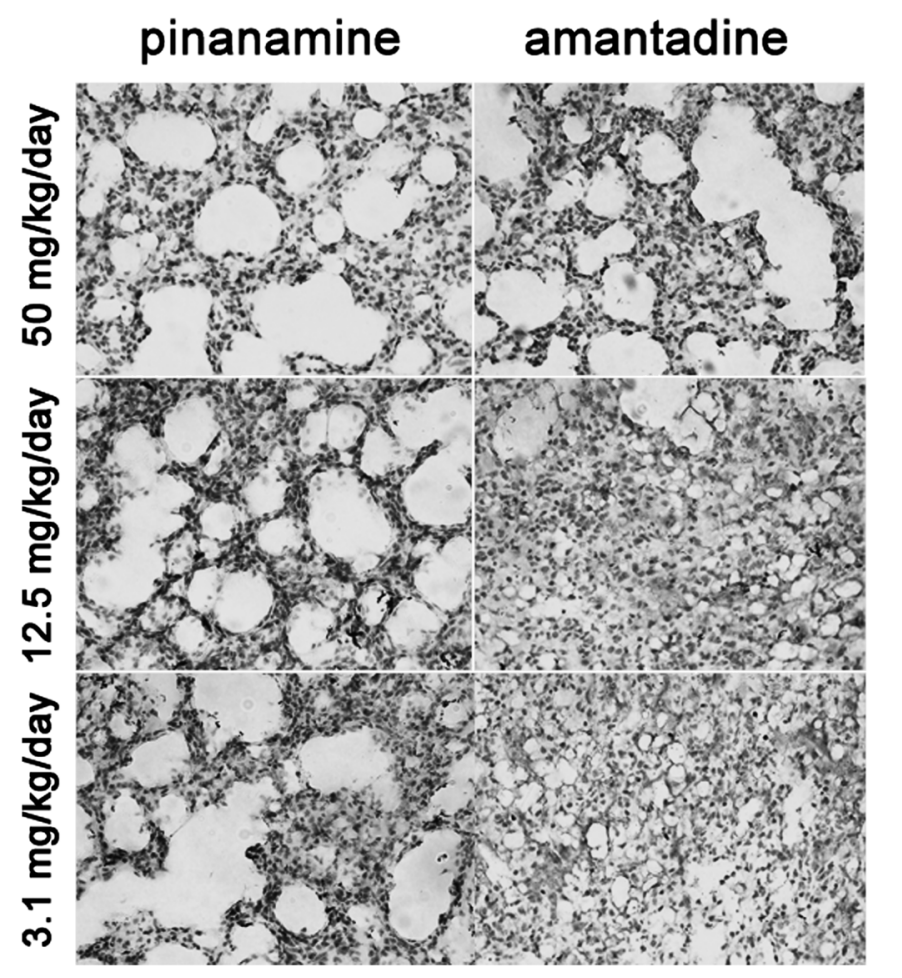

\section{normal control}

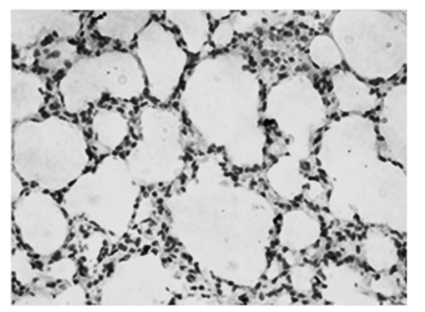

placebo

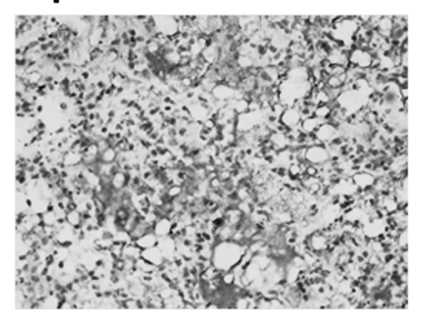

Fig. 2. Immunohistochemistry Analysis of Pinanamine on H1N1 Influenza Virus in Mice Lungs

Pinanamine was orally administered to mice at the indicated dosages as described above. Immunohistochemistry analysis of lungs in infected mice with or without treatment of pinanamine (original magnification: $\times 400$ ). Positivity is identified by gray staining in the cytoplasm.

mice were determined at day 5 post-infection, while lung index were measured on day 7. Immunohistochemical staining showed strong expression of influenza virus nucleoprotein in the cytoplasm of alveolar epithelial cells in placebo mice (Fig. 2). There were significantly lower expression of nucleoprotein in mice treated with pinanamine at all concentrations and $50 \mathrm{mg} / \mathrm{kg} / \mathrm{d}$ amantadine, but it did not improve in mice treated with 12.5 and $3.1 \mathrm{mg} / \mathrm{kg} / \mathrm{d}$ amantadine compared with the placebo (Fig. 2). In placebo group, the mean virus titer at day 5 was $8.75 \log \mathrm{TCID}_{50} / \mathrm{mL}$ (ranged from $8-9.5 \log \mathrm{TCID}_{50} / \mathrm{mL}$ ). Treatment of piananmine significantly resulted in 2000 -fold reduction by $50 \mathrm{mg} / \mathrm{kg} / \mathrm{d}$ (ranged from 5.25-6 $\left.\log \mathrm{TCID}_{50} / \mathrm{mL}\right)(p<0.01)$, and to a lesser degree, 130 -fold decrease by $12.5 \mathrm{mg} / \mathrm{kg} / \mathrm{d}$ (ranged from $\left.6-7.5 \log \mathrm{TCID}_{50} / \mathrm{mL}\right) \quad(p<0.01) \quad$ (Fig. 3A). Pinanamine dose of $3.1 \mathrm{mg} / \mathrm{kg} / \mathrm{d}$ reduced lung virus titer 56 -fold $(p<0.05)$, which was similar to amantadine dose of $50 \mathrm{mg} / \mathrm{kg} / \mathrm{d}$ (75-fold lower) $(p<0.05)$ (Fig. 3A). There was no significant difference in viral titers between the placebo and lower doses (3.1 and $12.5 \mathrm{mg} / \mathrm{kg} / \mathrm{d}$ ) of amantadine (Fig. 3A). Taken together, the viral load shown in lungs of mice correlates well with the expression degrees of influenza virus nucleoprotein, indicating that low dose pinanamine can exist similar efficacy to high dose amantadine in inhibiting virus replication in vivo.

As amantadine dosages of 12.5 and $3.1 \mathrm{mg} / \mathrm{kg} / \mathrm{d}$ possessed no effect on death protection and virus titer in mice, we employed $50 \mathrm{mg} / \mathrm{kg} / \mathrm{d}$ in lung index measurement. Lung index were significantly reduced by pinanamine treatment in all doses, with the most pronounced at $50 \mathrm{mg} / \mathrm{kg} / \mathrm{d} \quad(p<0.001)$ (Fig. 3B). Amantadine dose of $50 \mathrm{mg} / \mathrm{kg} / \mathrm{d}$ treated mice exhibited lower lung index compared with placebo treated groups $(p<0.05)$, and was similar to $3.1 \mathrm{mg} / \mathrm{kg} / \mathrm{d}$ piananmine (Fig. $3 \mathrm{~B})$. The lung index can serve as an indicator of lung damage triggered by virus invasion. This finding is consistent to virus replication (virus nucleoprotein and viral load) in lungs and the survival outcome of mice as described above.

\section{DISCUSSION}

Accumulating evidences have proved that amantadine occluded and arosterically inhibited M2 channel to block influenza virus replication. ${ }^{19,20)}$ The M2 channel remains an intriguing and promising target for designing selective inhibitors against influenza A virus, as amantadine-sensitive viruses re-emerge ${ }^{5,11}$ and binding sites of drug for evading drug resistance have been clarified. Using a scaffold-hopping strategy, we previously identified a novel M2 blocker, pinanamine. ${ }^{13)}$ As shown in supplementary Fig. 1, pinanamine is a two-ring-scaffold amine and amantadine is a three rings one. And shown in $3 \mathrm{D}$ model, the three methyl groups of pinanamine are helpful for occupying more space in the ion channel, this may enhance its activity for inhibition. The present study compared the potencies of pinanamine, oseltamivir carboxylate, ribavirin and amantadine against influenza A (H1N1) virus in vitro. Overall, pinanamine was slightly more effective than oseltamivir carboxylate and amantadine, and superior to ribavirin, but most toxic among compounds tested. These results were in accordance with those previously described for $\mathrm{A} / \mathrm{Hong}$ Kong/8/68 (H3N2), an amantadine-sensitive virus. ${ }^{13)}$

We further compared the efficacies of pinanamine and amantadine against an amantadine-sensitive H1N1 virus in vivo. Pinanamine exhibited marked potency at a $50 \mathrm{mg} / \mathrm{kg} / \mathrm{d}$ dosage, resulting in $100 \%$ death protection, and reduction in lung virus load as well as lung index compared with the placebo group. Even when the dosage was reduced to $3.1 \mathrm{mg} / \mathrm{kg} / \mathrm{d}$, the protective effect of pinanamine did not differ from that of 
A

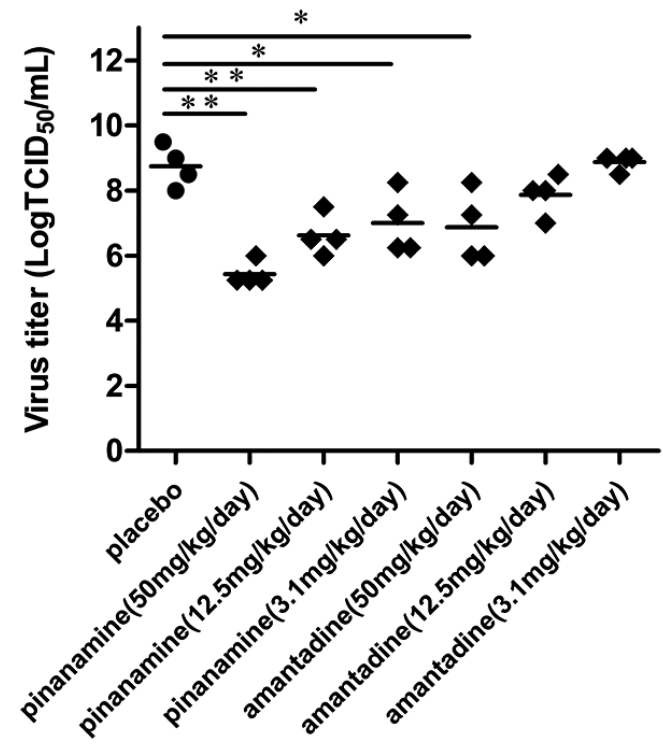

B

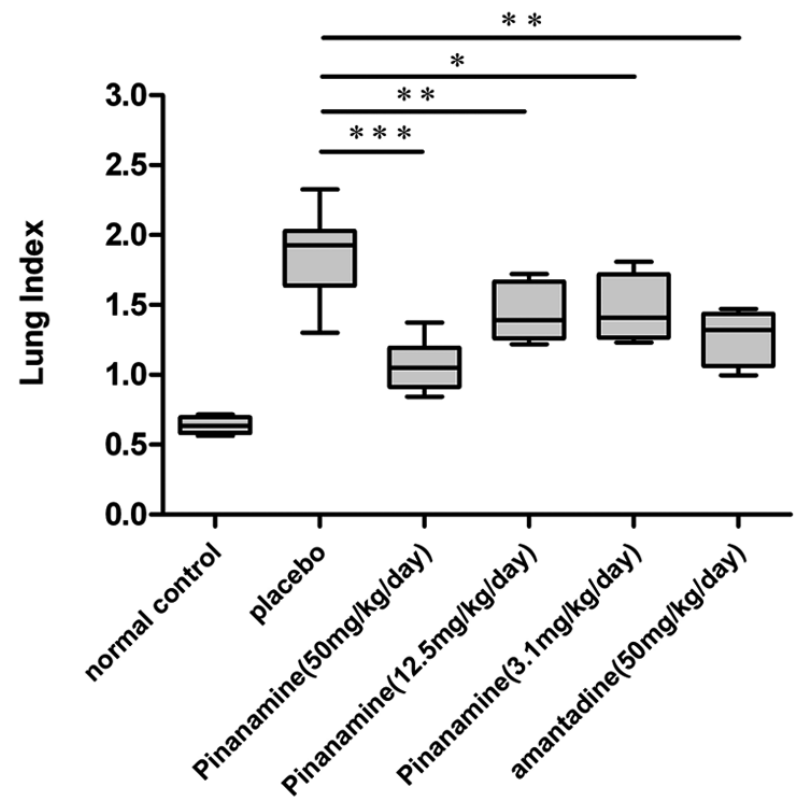

Fig. 3. Efficacy of Pinanamine on H1N1 Influenza Virus Replication in Mice Lungs

Pinanamine was orally administered to mice at the indicated dosages as described above. (A) Detection of virus recovered from lungs of mice on day 5 post infection. (B) The lung index was calculated as lung weight/body weight $\times 100$. $* p<0.05 ; * * p<0.01 ; * * * p<0.001$ when compared with the placebo-treated control group.

amantadine at $50 \mathrm{mg} / \mathrm{kg} / \mathrm{d}$. These differences between the dosages of the two drugs were approximately one order of magnitude. It is interesting to observe that, despite possessing a similar potency against influenza A virus in vitro, pinanamine protected mice from lethal challenges with $\mathrm{H} 1 \mathrm{~N} 1$ virus more effectively. The reason for this efficacy remains unknown. It might be attributed to different half-lives or bioavailabilities of pinanamine and amantadine.

The Centers for Disease Control and Prevention (CDC) guidance recommended $200 \mathrm{mg}$ per day of amantadine for children aged $\geq 10$ years and $\leq 100 \mathrm{mg}$ per day for persons aged $\geq 65$ years. $^{21)}$ The effective dose of pinanamine $(50 \mathrm{mg} / \mathrm{kg} / \mathrm{d})$ in mice amounts to $4.05 \mathrm{mg} / \mathrm{kg}$ per day for adult $(60 \mathrm{~kg})$ and $6 \mathrm{mg} / \mathrm{kg}$ per day for child $(20 \mathrm{~kg})$ according to the body surface area (BSA) calculation, ${ }^{22)}$ which is equivalent to
243 and $150 \mathrm{mg}$ per day for each. Despite similar estimated dosage to amantadine in human, the maximum tolerated dosage for pinanamine was between 250 and $100 \mathrm{mg} / \mathrm{kg} / \mathrm{d}$ in mice, which was higher than that of amantadine with $\mathrm{LD}_{50}$ of $1080 \mathrm{mg} / \mathrm{kg}$ by oral route. ${ }^{23)}$ The possible cause of death might contribute to acute damage to organs by pinanamine, and the toxicological mechanisms remain to be clarified. A desirable feature of antiviral agents requires fewer doses for reducing the risk of toxicity. One option to improve pinanamine treatment might be to optimize doses and duration of therapy (i.e., lower dose for longer treatment or larger time intervals of administration). Another possible choice might be combination therapy with the drugs affecting different factors, which provides advantage over single drug treatment in terms of reducing toxicity. We believe that rational use of pinanamine must further base on evidences of plasma or pulmonary half-lives, clarification on indication for use (i.e., chemoprophylaxis or therapy), as well as underlying medical conditions of the host.

The limited availability of anti-influenza agents has limited the use of combination strategies, resulting in the use of combinations of antivirals with identical targets (e.g., combinations of oseltamivir and peramivir to treat influenza A (H1N1) virus infections in cell culture and in mice). ${ }^{24)}$ In these cases, a negative outcome cannot be ruled out because resistant variants could still occur. Amantadine reportedly provides benefits in combination with oseltamivir and ribavirin. ${ }^{25,26)}$ Thus, pinanamine could offer a positive contribution to combination chemotherapy as a novel M2 inhibitor.

The important results of our study are that oral pinanamine showed better anti-influenza effects than amantadine in a mouse model and that the inhibition of M2 remains a rational and realistically significant goal, especially given the circulation of amantadine-sensitive human and avian influenza viruses. Furthermore, pinanamine has potential uses in combination chemotherapy. Taken together, these data show that pinanamine could be considered as a promising lead compound for the discovery of drugs active against influenza A virus. Further experiments should be carried out to investigate the possible structural modifications of pinanamine that could selectively inhibit amantadine-resistant variants with lower toxicity.

\section{CONCLUSION}

We have proven that the effect of pinanamine is superior to that of amantadine in vivo and pinanamine has potential use in combination chemotherapy. These findings indicate the promising potential of pinanamine for the discovery of drugs active against influenza $\mathrm{A}$ virus.

Acknowledgments This research was supported by funding from the State Key Laboratory of Respiratory Disease, the National Science Fund of China (Grant No. 81471937), the National Science Fund of China (Grant No. U1301224) and the Guangzhou Municipal Science and Technology Program (Grant No. 1201410111).

Conflict of Interest The authors declare no conflict of interest.

Supplementary Materials The online version of this ar- 
ticle contains supplementary materials.

\section{REFERENCES}

1) Webster RG, Bean WJ, Gorman OT, Chambers TM, Kawaoka Y. Evolution and ecology of influenza A viruses. Microbiol. Rev., 56, 152-179 (1992)

2)〈http://www.who.int/influenza/human_animal_interface/avian_influ enza/archive/en/s,

3) Nicholson KG, Wood JM, Zambon M. Influenza. Lancet (London), 362, 1733-1745 (2003).

4) Kwon H-i, Song M-S, Pascua PNQ, Baek YH, Lee JH, Hong S-P, Rho J-B, Kim J-K, Poo H, Kim C-J, Choi YK. Genetic characterization and pathogenicity assessment of highly pathogenic H5N1 avian influenza viruses isolated from migratory wild birds in 2011, South Korea. Virus Res., 160, 305-315 (2011).

5) Gutiérrez RA, Naughtin MJ, Horm SV, San S, Buchy P. A (H5N1) virus evolution in south east Asia. Viruses, 1, 335-361 (2009).

6) $\mathrm{Wu} \mathrm{Y,} \mathrm{Gao} \mathrm{GF.} \mathrm{Lessons} \mathrm{learnt} \mathrm{from} \mathrm{the} \mathrm{human} \mathrm{infections} \mathrm{of} \mathrm{avian-}$ origin influenza A H7N9 virus: live free markets and human health. Sci. China Life Sci., 56, 493-494 (2013).

7) http://www.fao.org/ag/againfo/programmes/en/empres/H7N9/situa tion update.html.

8) Boltz DA, Aldridge JR Jr, Webster RG, Govorkova EA. Drugs in development for influenza. Drugs, 70, 1349-1362 (2010).

9) Baz M, Abed Y, Papenburg J, Bouhy X, Hamelin M-E, Boivin G. Emergence of oseltamivir-resistant pandemic H1N1 virus during prophylaxis. N. Engl. J. Med., 361, 2296-2297 (2009).

10) Cheng PK, Leung TW, Ho EC, Leung PC, Ng AY, Lai MY, Lim WW. Oseltamivir-and amantadine-resistant influenza viruses A (H1N1). Emerg. Infect. Dis., 15, 966-968 (2009).

11) Furuse Y, Suzuki A, Shimizu M, Kishi M, Sawayama R, Saito M, Fuji N, Nukiwa N, Oshitani H. Reassortment between amantadineresistant and -sensitive H1N1 influenza A viruses generated an amantadine-sensitive virus during the 2007-2008 season. J. Infect. Dis., 200, 1766-1773 (2009).

12) De Clercq E. Antiviral agents active against influenza A viruses. Nat. Rev. Drug Discov., 5, 1015-1025 (2006).

13) $\mathrm{Hu} \mathrm{W}$, Zeng S, Li C, Jie Y, Li Z, Chen L. Identification of hits as matrix-2 protein inhibitors through the focused screening of a small primary amine library. J. Med. Chem., 53, 3831-3834 (2010).

14) Zhao X, Li C, Zeng S, Hu W. Discovery of highly potent agents against influenza A virus. Eur. J. Med. Chem., 46, 52-57 (2011).

15) Zhao X, Jie Y, Rosenberg MR, Wan J, Zeng S, Cui W, Xiao Y, Li
Z, Tu Z, Casarotto MG, Hu W. Design and synthesis of pinanamine derivatives as anti-influenza A M2 ion channel inhibitors. Antiviral Res., 96, 91-99 (2012).

16) Dong J, Chen S, Li R, Cui W, Jiang H, Ling Y, Yang Z, Hu W. Imidazole-based pinanamine derivatives: Discovery of dual inhibitors of the wild-type and drug-resistant mutant of the influenza A virus. Eur. J. Med. Chem., 108, 605-615 (2016).

17) Reed LJ, Muench H. A simple method of estimating fifty percent endpoints. Am. J. Epidemiol., 27, 493-497 (1938).

18) Zhu Z, Yang Y, Feng Y, Shi B, Chen L, Zheng Y, Tian D, Song Z, Xu C, Qin B, Zhang X, Guan W, Liu F, Yang T, Yang H, Zeng D, Zhou W, Hu Y, Zhou X. Infection of inbred BALB/c and C57BL/6 and outbred Institute of Cancer Research mice with the emerging H7N9 avian influenza virus. Emerg. Microbes. Infect., 2, e50 (2013).

19) Cady SD, Schmidt-Rohr K, Wang J, Soto CS, DeGrado WF, Hong M. Structure of the amantadine binding site of influenza M2 proton channels in lipid bilayers. Nature, 463, 689-692 (2010).

20) Kozakov D, Chuang G-Y, Beglov D, Vajda S. Where does amantadine bind to the influenza virus M2 proton channel. Trends Biochem. Sci., 35, 471-475 (2010).

21) Fiore AE, Fry A, Shay D, Gubareva L, Bresee JS, Uyeki TM. Antiviral agents for the treatment and chemoprophylaxis of influenzarecommendations of the Advisory Committee on Immunization Practices (ACIP). MMWR Recomm. Rep., 60, 1-24 (2011).

22) Reagan-Shaw $\mathrm{S}$, Nihal M, Ahmad N. Dose translation from animal to human studies revisited. FASEB J., 22, 659-661 (2008).

23) Davies WL, Grunert RR, Haff RF, McGahen JW, Neumayer EM, Paulshock M, Watts JC, Wood TR, Hermann EC, Hoffmann CE. Antiviral activity of 1-adamantanamine (amantadine). Science, 144, 862-863 (1964)

24) Duval X, van der Werf S, Blanchon T, Mosnier A, BouscambertDuchamp M, Tibi A, Enouf V, Charlois-Ou C, Vincent C, Andreoletti L, Tubach F, Lina B, Mentre F, Leport C. Efficacy of oseltamivir-zanamivir combination compared to each monotherapy for seasonal influenza: a randomized placebo-controlled trial. PLoS Med., 7, e1000362 (2010).

25) Ilyushina NA, Hoffmann E, Salomon R, Webster RG, Govorkova EA. Amantadine-oseltamivir combination therapy for $\mathrm{H} 5 \mathrm{~N} 1$ influenza virus infection in mice. Antivir. Ther., 12, 363-370 (2007).

26) Nguyen JT, Hoopes JD, Smee DF, Prichard MN, Driebe EM, Engelthaler DM, Le MH, Keim PS, Spence RP, Went GT. Triple combination of oseltamivir, amantadine, and ribavirin displays synergistic activity against multiple influenza virus strains in vitro. Antimicrob. Agents Chemother., 53, 4115-4126 (2009). 